\title{
Hubungan Antara Evaluasi Pembelajaran Teori dan Praktik Laboratorium Asuhan Kebidanan Persalinan Di Akademi Kebidanan Farama Mulya
}

\author{
$\underline{\text { Dina Martha Fitri }{ }^{1}, \text { Nurhidayah }^{2}}$ \\ D-IV Bidan Pendidik STIKes Mitra RIA Husada \\ Alamat e-mail : marthadina@ymail.com
}

\begin{abstract}
ABSTRAK
Tujuan penelitian untuk mengetahui distribusi frekuensi dan hubungan antara evaluasi pembelajaran teori dan praktik asuhan kebidanan persalinan. Pembelajaran merupakan sistem yang terdiri atas beberapa unsur, yaitu masukan, proses dan keluaran atau hasil. Dalam pendidikan bidan, evaluasi dilakukan tidak hanya untuk mengukur keberhasilan dalam teori tetapi juga dilakukan evaluasi untuk praktik laboratorium.

Penelitian ini menggunakan penelitian analitik dengan desain pendekatan Korelasional untuk meneliti sejauh mana variasi pada suatu faktor berkaitan dengan variasi faktor lain berdasarkan koefisien korelasi dengan cara mendokumentasikan rekapitulasi nilai teori dan praktik laboratorium asuhan kebidanan persalinan mahasiswa semester V sebanyak 84 mahasiswa.

Hasil penelitian evaluasi pembelajaran teori asuhan kebidanan dinyatakan lulus yaitu sebanyak 81 mahasiswa (96,4\%). Sedangkan untuk evaluasi pembelajaran praktik laboratorium asuhan kebidanan persalinan yang dinyatakan lulus sebanyak 82 mahasiswa (97,6\%). Adapun hasil uji korelasi memiliki hubungan positif dan signifikan antara evaluasi pembelajaran teori dan praktik laboratorium asuhan kebidanan persalinan.

Kesimpulan diharapkan mahasiswa harus menguasai teori asuhan kebidanan persalinan tetapi mahir dalam melakukan praktik laboratorium asuhan kebidanan persalinan. Berdasarkan kesimpulan hasil penelitian, maka peneliti memberikan saran untuk Akademi Kebidanan Farama Mulya untuk tetap meningkatkan proses pembelajaran yang terdiri dari unsur masukan, proses dan hasil pembelajaran.
\end{abstract}

Kata kunci : Evaluasi pembelajaran teori dan praktik laboratorium 


\section{Pendahuluan}

Tenaga bidan merupakan salah satu tenaga kesehatan utama sebagai ujung tombak pembangunan kesehatan dalam upaya percepatan penurunan AKI dan AKB. Untuk itu dibutuhkan tenaga bidan yang terampil melakukan prosedur klinis dengan kemampuan analisis kritis, dan tepat dalam penatalaksanaan asuhan pada perempuan. Keterlibatan bidan dalam asuhan normal dan fisiologis sangat menentukan demi penyelamatan jiwa ibu dan bayi oleh karena wewenang dan tanggung jawab profesionalnya sangat berbeda dengan tenaga kesehatan lain (Kepmenkes RI, 2010).

Pendidikan tenaga kesehatan didirikan untuk menghasilkan tenaga kesehatan dalam jumlah dan jenis serta mutu yang disesuaikan dengan tuntunan masyarakat. Dalam zaman modern ini dituntut adanya sumber daya manusia yang mampu bekerja secara mahir dalam segala bidang termasuk upaya pelayanan kesehatan. Peranan tenaga kesehatan sangat menentukan keberhasilan pelaksanaan program pembangunan di bidang kesehatan untuk mencapai visi Indonesia sehat 2025.

Salah satu strategi mencapai Indonesia sehat 2025 adalah peningkatan kualitas sumber daya tenaga kesehatan melalui pendidikan tenaga kesehatan yang professional. Pendidikan tenaga kesehatan professional tersebut diawali dan proses pendidikan yang baik dimana peserta didik tidak hanya mendapat pendidikan di kelas dalam bentuk kuliah, seminar dan diskusi, tetapi juga proses pembelajaran klinik yang dilakukan di laboratorium dan dilahan praktek. Pengajaran dan pembelajaran praktik laboratorium merupakan hal yang sangat menentukan kualitas lulusan. Ironisnya dalam praktek pendidikan ini banyak sekali hambatannya, seperti kasus yang terbatas, jumlah pembimbing yang terbatas dan dosen klinik yang waktunya terbatas untuk mengajar mahasiswi (Titik Puji Lestari, 2010).

Pembelajaran merupakan sistem yang terdiri atas beberapa unsur, yaitu masukan, proses dan keluaran atau hasil. Dalam pendidikan bidan, evaluasi dilakukan tidak hanya untuk mengukur keberhasilan dalam teori tetapi juga dilakukan evaluasi untuk praktik laboratorium. Evaluasi hasil pembelajaran antara lain menggunakan tes untuk melakukan pengukuran hasil belajar sebagai prestasi belajar, dalam hal ini adalah penguasaan kompetensi oleh setiap mahasiswi (Tim PEKERTI-AA, 2007).

Sasaran evaluasi hasil belajar mahasiswi adalah penguasaan kompetensi. Dalam hal ini kompetensi diartikan sebagai; (1) Seperangkat tindakan cerdas penuh tanggung jawab yang dimiliki seseorang sebagai syarat untuk dianggap mampu oleh masyarakat dalam melaksanakan tugas-tugas di bidang pekerjaan tertentu (SK. Mendiknas No. 045/U/2002); (2) Kemampuan yang dapat dilakukan oleh peserta didik yang mencakup pengetahuan, keterampilan dan perilaku; (3) Integrasi domain kognitif, afektif, dan psikomotorik yang direfleksikan dalam perilaku. Mengacu pengertian kompetensi tersebut, maka hasil belajar mahasiswi mencakup ranah kognitif, psikomotorik dan afektif yang harus dikuasai oleh setiap mahasiswi setelah pembelajaran berlangsung sesuai dengan rencana pembelajaran yang disusun oleh dosen. (Tim PEKERTI-AA, 2007).

Ranah kognitif dan afektif dapat dinilai dengan memberikan tes yang berbentuk obyektif maupun uraian. Sedangkan ranah psikomotor penilaian dapat menggunakan alat ukur berupa daftar cek (check list), skala nilai (rating scale), catatan anekdotal (anecdotal record), dan skala produk. Daftar cek (checklist) biasa digunakan untuk menilai keterampilan yang telah diberikan di laboratorium, khususnya bagi mahasiswi kebidanan. Menurut kurikulum pendidikan bidan nasional tahun 2002, ditentukan $40 \%$ untuk pembelajaran teori dan $60 \%$ untuk pembelajaran di laboratorium (Tim penyusun, 2006)

Diharapkan mahasiswi tidak hanya pandai dalam teori tapi juga praktek asuhan persalinan normal. Karena setelah terjun di masyarakat seorang bidan dituntut dapat menekan angka kematian ibu dengan melakukan asuhan persalinan normal dengan benar. Karena itu 
diharapkan setelah mahasiswi lulus dievaluasi untuk teori, maka mahasiswi juga harus lulus dievaluasi praktik laboratorium asuhan kebidanan persalinan. Karena sesuai dengan salah satu sasaran evaluasi hasil belajar yaitu, kemampuan yang dapat dilakukan oleh peserta didik yang mencakup pengetahuan, keterampilan dan perilaku.

Berdasarkan survey pendahuluan yang didapat, pada tahun 2013-2014 seluruh mahasiswi dengan jumlah 78 orang dinyatakan lulus pada mata kuliah asuhan kebidanan persalinan baik teori maupun praktik laboratorium. Dan pada tahun ajaran 2014-2015 seluruh mahasiswi dengan jumlah 118 orang juga dinyatakan lulus pada mata kuliah asuhan kebidanan persalinan baik teori maupun praktik laboratorium.

Berdasarkan data di atas, maka penulis tertarik mengadakan penelitian untuk mengetahui apakah ada hubungan antara evaluasi pembelajaran teori dan praktik laboratorium asuhan kebidanan persalinan di Akademi Kebidanan Farama Mulya tahun 2016.

\section{Tujuan Umum}

Untuk mengetahui Hubungan Antara Evaluasi Pembelajaran Teori dan Praktik Laboratorium Asuhan Kebidanan Persalinan di Akademi Kebidanan Farama Mulya Tahun 2018 .

\section{Tujuan Khusus}

a. Diketahuinya evaluasi pembela-jaran teori asuhan kebidanan persalinan.

b. Diketahuinya evaluasi pembela-jaran praktik laboratorium asuhan kebidanan persalinan.

c. Diketahuinya analisis hubungan evaluasi pembelajaran teori dan praktik laboratorium asuhan kebidanan persalinan.

\section{Metode Penelitian}

Penelitian ini menggunakan penelitian analitik dengan desain pendekatan Korelasional dan Regresi Linier. Sampel dalam penelitian ini adalah seluruh mahasiswi semester V Akademi Kebidanan Farama Mulya tahun2018.

\section{Hasil Penelitian}

Analisis Univariat

Tabel 5.1.1

Distribusi Frekuensi Responden Berdasarkan Evaluasi Pembelajaran Teori Dan Praktik Laboratorium Asuhan Kebidanan Persalinan di Akademi Kebidanan Farama Mulya Tahun 2018

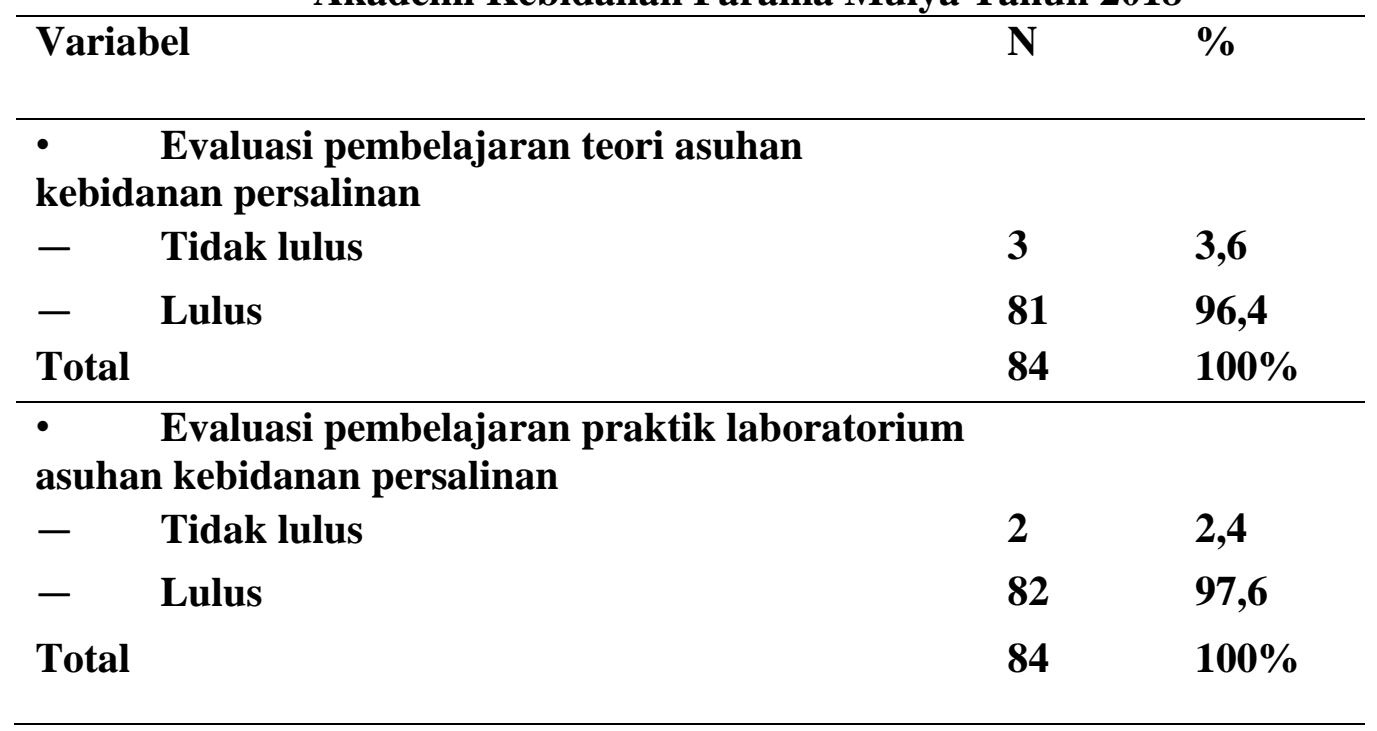


Tabel 5.1.1 menunjukan bahwa distribusi frekuensi evaluasi pembelajaran teori dan praktik laboratorium asuhan kebidanan persalinan yang diperoleh mahasiswi. Mahasiswi yang dinyatakan tidak lulus pembelajaran teori asuhan kebidanan persalinan sebanyak 3 mahasiswi (3,6\%) dan dinyatakan lulus lebih banyak yaitu sebanyak 81 mahasiswi $(96,4 \%)$. Sedangkan untuk pembelajaran praktik laboratorium asuhan kebidanan persalinan yang dinyatakan tidak lulus sebanyak 2 mahasiswi $(2,4 \%)$ dan dinyatakan lulus sebanyak 82 mahasiswi $(97,6 \%)$.

Analisis Bivariat

Tabel 5.2.1

Analisis Korelasi Evaluasi Pembelajaran Teori Dengan Praktik Laboratorium Asuhan Kebidanan Persalinan di Akademi Kebidanan Farama Mulya

Tahun 2018

\begin{tabular}{|c|c|c|c|c|}
\hline Variabel & $\mathrm{r}$ & $\mathrm{R}^{2}$ & Persamaan garis & $P$ Value \\
\hline $\begin{array}{l}\text { Evaluasi } \\
\text { Pembelajaran } \\
\text { Teori Asuhan } \\
\text { Kebidanan } \\
\text { Persalinan }\end{array}$ & 0,383 & 0,147 & $\begin{array}{l}\text { Evaluasi Pembelajaran Praktik } \\
\text { Laboratorium }=60.703+0,302 * \text { Evaluasi } \\
\text { Pembelajaran Teori Asuhan Kebidanan } \\
\text { Persalinan }\end{array}$ & 0,000 \\
\hline
\end{tabular}

Hubungan evaluasi pembelajaran teori asuhan kebidanan persalinan dengan evaluasi pembelajaran praktik laboratorium menunjukan hubungan sedang $(\mathrm{r}=0,383)$ dan berpola positif artinya semakin mahasiswi meguasai teori mata kuliah asuhan kebidanan persalinan maka semakin bagus dalam hal praktik laboratorium asuhan kebidanan persalinan.

Nilai koefisien dengan determinasi 0,147 artinya, persamaan garis regresi yang kita peroleh dapat menerangkan $14,7 \%$ variasi evaluasi pembelajaran praktik laboratorium atau persamaan garis yang diperoleh cukup baik untuk menjelaskan variabel evaluasi pembelajaran praktik laboratorium asuhan kebidanan persalinan.

Hasil uji statistik didapatkan ada hubungan yang signifikan antara evaluasi pembelajaran teori dengan evaluasi pembelajaran praktik laboratorium asuhan kebidanan persalinan $(\mathrm{p}=0,00)$.

\section{Pembahasan}

\section{Analisa Evaluasi Pembelajaran Teori Pada Evaluasi Pembelajaran Praktik Laboratorium Asuhan Kebidanan Persalinan}

Dari hasil penelitian menunjukan bahwa hubungan evaluasi pembelajaran teori asuhan kebidanan persalinan pada evaluasi pembelajaran praktik laboratorium asuhan kebidanan persalinan di Akademi Kebidanan Farama Mulya pada tahun 2016 memiliki hubungan positif dengan nilai $(r)=0,383$ Sehingga hipotesis diterima.

Data diatas sesuai dengan teori Muhibbin (2004), ketrampilan bukan hanya meliputi gerak motorik saja melainkan juga pengejawa-ntahan fungsi mental yang bersifat kognitif. Jadi keberhasilan pengem-bangan ranah kognitif berdampak positif terhadap pengembangan ranah psikomotor. Sasaran evaluasi hasil belajar mahasiswi adalah penguasaan kompetensi. Dalam hal ini kompetensi diartikan sebagai; (1) Seperangkat tindakan cerdas penuh tanggung jawab yang dimiliki seseorang sebagai syarat untuk dianggap mampu oleh masyarakat dalam melaksanakan tugas-tugas di bidang pekerjaan tertentu (SK. Mendiknas No. 045/U/2002); (2) Kemampuan yang dapat dilakukan oleh peserta didik yang mencakup 
pengetahuan, keterampilan dan perilaku; (3) Integrasi domain kognitif, afektif, dan psikomotorik yang direfleksikan dalam perilaku (Tim PEKERTI, 2007).

Evaluasi pencapaian belajar siswa tidak hanya menyangkut aspek-aspek kognitifnya, tetapi juga mengenai aplikasi atau performance, aspek afektif yang menyangkut sikap serta interalisasi nilai-nilai yang perlu ditanamkan dan dibina melalui mata ajaran atau mata kuliah yang telah diberikannya (Purwanto, 2008).

Hasil dari penelitian sebelumnya juga menunjukkan hasil yang sama. Menurut Hastutik (2006), dengan judul penelitian, "Korelasi Antara Hasil Evaluasi Kognitif Dengan Kemampuan Psikomotor Pada Mata Kuliah Ketrampilan Dasar Praktik Klinik (KDPK) Mahasiswi Semester I Akbid Mitra Husada Karanganyar Tahun Akademik 2005/2006" menge-mukakan terdapat korelasi yang positif dan signifikan antara hasil evaluasi kognitif dengan kemampuan psikomotor pada mata kuliah ketrampilan dasar praktik klinik (KDPK).

\section{SIMPULAN \\ Simpulan}

Berdasarkan hasil penelitian yang diperoleh dan sesuai dengan tujuan khusus maka peneliti mengambil kesimpulan sebagai berikut :

a. Diketahui $96 \%$ mahasiswi dinyatakan lulus dalam evaluasi pembelajaran teori asuhan kebidanan persalinan dan 98\% mahasiswi dinyatakan lulus dalam evaluasi pembelajaran praktik laboratorium asuhan kebidanan persalinan

b. Terdapat hubungan yang positif dengan nilai $(r)=0,383$ dan signifikan dengan nilai $(\mathrm{p}=0,00)$ antara evaluasi pembelajaran teori asuhan kebidanan persalinan pada evaluasi pembelajaran praktik labora-torium asuhan kebidanan persalinan.

\section{Saran}

\section{Teoritis}

Diharapkan dapat meningkatkan proses pembelajaran yang terdiri dari unsur masukan, proses dan hasil pembelajaran dan dapat memberikan kontribusi bagi perkembangan konsep keilmuan tentang asuhan kebidanan persalinan.

\section{Praktik}

Diharapkan dapat memberikan pembelajaran asuhan kebidanan persalinan yang bermakna sehingga mahasiswi bukan hanya memahami teori tetapi juga terampil dalam melakukan praktik laboratorium asuhan kebidanan persalinan.

\section{Referensi}

Arikunto, Suharsimi. 2013. Dasar-Dasar Evaluasi Pendidikan. Jakarta : Bumi Aksara. Budiarto. 2002. Biostatistik Untuk Kedokteran dan Kesehatan Masyarakat. Jakarta : EGC Hastutik. 2006. Korelasi Antara Hasil Evaluasi Kognitif Dengan Kemampuan Psikomotor Pada Mata Kuliah Ketrampilan Dasar Praktik Klinik (KDPK) Mahasiswa Semester I Akbid Mitra Husada Karanganyar Tahun Akademik 2005/2006. Surakarta: Program Studi D IV Kebidanan FK UNS.

JNKP-KR, (2008), Pelatihan Bidan APN, Departemen Kesehatan: Jakarta

Kemenkes RI. Standar Laboratorium Kebidanan. Pusat Pendidikan Tenaga Kesehatan: Kemenkes RI; 2010.

Muhibbin, S. 2004. Psikologi Pendidikan. Bandung: Remaja Rosdakarya.

Notoatmodjo. 2005. Metodologi Penelitian Kesehatan. Jakarta : Rineka Cipta 
PP IBI. 2004. SK. Mendiknas No. 045/U/2002.

Purwanto, N. 2008. Prinsip-prinsip dan Teknik Evaluasi Pengajaran. Bandung: PT Rosdakarya Offset.

Sujianti, 2009. Buku Ajar Konsep Kebidanan Teori dan Aplikasi. Jakarta : Numed Tim PEKERTI-AA PPSP LPP UNS. 2007. Panduan Evaluasi Pembelajaran. Surakarta: Lembaga Pengembangan Pendidikan. Available on:http://lpp.uns.ac.id. 12 Oktober 2016.

Tim Penyusun. 2006. Panduan Praktikum Asuhan Kebidanan pada Ibu Bersalin. Karanganyar: Akademi Kebidanan Mitra Husada Karanganyar.

Titik Puji Lestari. 2010. Efektifitas Metode Pembelajaran Bedside Teaching Terhadap Tingkat Pengetahuan dan Kemampuan Psikomotor Mahasiswa DIII Dilahan Praktik RSUD Dr, Harjoni Ponorog (Karya Tulis). Jawa Timur. 